\title{
A Comparative Study on Fly Ash and Bagasse Ash Using as a Sub-Grade Material
}

\author{
Gazi Mohammad Harun-Or-Rashid, Mohammad Farhadur Rahman, Abu Bakar Siddique
}

Department of Civil Engineering, Rajshahi University of Engineering \& Technology, Rajshahi, Bangladesh

\section{Email address:}

farhad.civil.ruet@gmail.com (M. F. Rahman)

\section{To cite this article:}

Gazi Mohammad Harun-Or-Rashid, Mohammad Farhadur Rahman, Abu Bakar Siddique. A Comparative Study on Fly Ash and Bagasse Ash Using as a Sub-Grade Material. American Journal of Civil Engineering. Vol. 7, No. 4, 2019, pp. 82-87. doi: 10.11648/j.ajce.20190704.11

Received: May 21, 2019; Accepted: July 10, 2019; Published: August 8, 2019

\begin{abstract}
Expansive soil is prone to large volume changes (swelling and shrinking) that are directly related to changes in moisture. So the low bearing strength and high compressibility behavior of soil can cause severe damage to subgrade. In this research the enumeration of the strength of soil by adding different types of ground improvement materials like as fly ash and bagasse ash in order to overcome such type of damages. The California Bearing Ratio (CBR) test to determine the stability of subgrade soil by adding fly-ash and bagasse ash separately at different percentages. The objective of this paper is to study the combined effects of Fly Ash and Bagasse Ash on Maximum Dry Density (MDD), Optimum Moisture Content (OMC), Soaked CBR and Swelling pressure of expansive soil. The effects of molding water content and compaction delay, on soaked CBR of both Ashes stabilized expansive soil have also been studied. CBR tests were performed with fly-ash and bagasse ash separately at different percentage variations with the increment of $2.5 \%$ by weight in order to find out which one is most suitable for stabilization of subgrade material. The results show that initially the optimum moisture content (OMC) of soil is $13.5 \%$ and for addition of fly ash and bagasse ash separately up to $12.5 \%$ it has become in increase up to $19.1 \%$ and $15.26 \%$ respectively. Initially the CBR value of soil is $6.63 \%$. For addition of bagasse ash up to $10 \%$ the CBR value of soil has become in increase up to $13.87 \%$ and after then for addition of $12.5 \%$ bagasse ash it has become in decrease $13.42 \%$. For fly ash the CBR value for $10 \%$ is $15.11 \%$, which is larger than the bagasse ash.
\end{abstract}

Keywords: Expansive Soil, Fly Ash, Bagasse Ash, Swelling Index, MDD, OMC, CBR

\section{Introduction}

Sand, silt and clay are the three basic types of soil. Clay soils are generally considered as "expansive soil". Construction of highways and runways over expansive soils is one of the tremendous civil engineering running issue throughout the world due to the fact expansive soils have the tendency to shrink and swell with variation in moisture content. During monsoon expansive soil absorb water and tend to expand in volume. Similarly, in drier season like summer it will shrink because water is drawn away [1]. In semi-arid and arid regions of the globe, expansive soils are generally found which has destructive effect on the nature unless it is treated, causes huge damage to the structure built on it as well as loss of human life (Mohanty, 2015). The properties of soil can be improved by stabilization with admixtures such as lime; cement; fly ash; bagasse ash and cement kiln dust are used to improve the qualities of various types of soils such as Lateritic Soil [19], Clayey soil. In this research fly ash and bagasse ash are separately used for the purpose of stabilization of expansive soil.

A waste material extracted from the gases emanating from coal fired furnaces is called fly ash. Fly ash is a waste by product from thermal power plants. The main objective of volcanic ashes in the ancient periods were the use of it as hydraulic cements and fly ash bears almost same property to these volcanic ashes. These ashes were believed to be one of the best binding agent used in and around the world. But it covers thousands hectares of precious land for its disposal and also causing not only severe health problem but also environmental hazards. Considering the fact, the proper management of this is essential for our sound survival. Also of its great availability and its low cost, the possibility of its usage is investigated here [2-4].

Utilization of fly ash has led to international standards, specifications and practices for classification and usage. 
According to ASTM C618, "Standard Specification for Coal Fly Ash and Raw or Calcined Natural Pozzolan for Use in Concrete" classification, fly ashes are classified as either Class F or Class C. Class F fly ash has pozzolanic properties whereas Class $\mathrm{C}$ fly ash has both pozzolanic and cementitious properties. Class $\mathrm{C}$ fly ash is also referred to as high calcium fly ash because it typically contains more than 10 percent $\mathrm{CaO}$. The high $\mathrm{CaO}$ content mainly contributes to self-cementing property in the presence of water. Hydration of fly ash is defined as formation of cementitious material by the reaction of $\mathrm{CaO}$ with the pozzolans $\left(\mathrm{SiO}_{2}, \mathrm{Al}_{2} \mathrm{O}_{3}, \mathrm{Fe}_{2} \mathrm{O}_{3}\right)$ in the presence of water. The hydrated calcium silicate gel or calcium aluminate gel cementitious material alike can bind with the inert material together (Transportation Research Board, 1987). About $40-45 \%$ of the fibrous residue from sugarcane after crushing and extraction of its juice is known as "Bagasse". Mr. Lavanya M. R et al. (1980) [3] studied the compressive strength of concrete by partial replacement of cement with sugarcane bagasse ash. The feasibility of using sugarcane bagasse ash ina finely grounded state, as partial replacement for cement in conventional concrete is examined. The tests were conducted as per Bureau of Indian Standard (BIS) codes to evaluate the stability of SCBA for partial replacement up to $30 \%$ of cement with varying water cement $(\mathrm{W} / \mathrm{C})$ ratio. They showed that addition of SCBA results in improvement of strength in all cases and as per the results obtained. It was concluded that bagasse ash can increase the overall strength of concrete when used up to $15 \%$ cement replacement level with $\mathrm{W} / \mathrm{C}$ ratio of 0.35 . American Society for Testing and Materials, ASTM C33 (1978) [2] discussed the properties of various aggregates and sub base strata. Chemical properties like chloride action, carbon content and other organic constituents of various agro materials were discussed. On comparison of above properties, it was justified that certain proportion of fine aggregate can be substituted in normal concrete with suitable proportion of agro wastes like Bagasse ash. Generally, it is reused as fuel in boilers for heat generation which leaves out $8-10 \%$ of ash, known as Sugar Cane Bagasse Ash, which is treated as waste and unutilized. Sugarcane bagasse consists of approximately $50 \%$ of cellulose, $25 \%$ of hemicelluloses and $25 \%$ of lignin. Bagasse ash is a non-cohesive material having a low specific gravity. It contains a massive amount of silica and when it is burnt it behaves as binding material. But the use of sugarcane bagasse as bio fuel or burning in open fields leads to a pressuring environmental threat of polluting air, water etc. On the other hand the disposal of this material is already causing environmental problems around the sugar factories. After realizing the overall facts it can be used as for the stabilization of road subgrade $[5,6]$.

A number of researches have been carried out in the recent past on the use of fly ash and sugarcane bagasse ash in the development of road subgrade. The characteristics and strength of a highly expansive soil can be amended by using fly ash stabilization. The plasticity index of the soil can be enhanced by using fly ash treatment. Since there is much more fly ash that is disposed off rather than utilized that makes more productive use of fly ash and finally get considerable environmental benefits [6]. Phanikumar and Sharma showed that by using $20 \%$ fly ash the plasticity of soil reduced by $50 \%$ [7]. Also optimum moisture content is increased with the addition of ash in the compaction tests by increasing the soil great specific surface and decreasing the maximum dry density because of a lower specific weight. Ahmed also suggests that the fly ash can be applied in soils that contain a high percentage of moisture resulting in greater compaction due to the evaporation of a considerable quantity of the contained moisture (Ahmed, 2014). Another paper showed that maximum dry density obtained from modified Proctor test decreases with increasing fly ash content and there is no consistent variation in optimum moisture content with increasing fly ash content [8]. In another case [9], the maximum dry density decreases and the optimum moisture content increases with the addition of bagasse ash and from the test results it has found that the optimum percentage of bagasse ash is $9 \%$. It is also found that soil properties improved more when bagasse ash mix with lime stabilized soil. CBR value increased and maximum dry density (MDD) also increased and it results well on lime proportion at $8 \%$ and bagasse ash at 6\% [10]. Kanchan Lata Singh and S M Ali Jawaid [11] presented the stabilization of soil using bagasse ash in percentage of $0 \%, 3 \%, 6 \%, 9 \%, 12 \%, 21 \%$ and $30 \%$. According to the study with increase in percentage of bagasse ash the MDD of mix is decreasing and CBR value of the soil increasing upto an optimum percentage of bagasse ash in mix. With the increase in CBR value the strength characteristics of clayey soil was increased. Kiran R. G., Kiran L [12] had studied 'The analysis of Strength Characteristics of Black Cotton Soil Using Bagasse Ash and Additives as Stabilizer". In this study the black cotton soil is taken from Harihara, Davanagere district, Karnataka. Under this study laboratory experiments are carried out for different percentages $(4 \%, 8 \%$ and $12 \%)$ of bagasse ash and additive mix proportions. The strength parameters like CBR, UCS are determined. It is observed that, the blend results of bagasse ash with different percentage of cement for black cotton soil gave change in density, CBR and UCS values.

\section{Experimental Investigation}

\subsection{Materials and Methods}

The expansive soil used in this study was collected from Godagari Upazila in the district of Rajshahi in Bangladesh. The soil sample was collected from the about 5 feet below from the ground level. The admixtures used in this investigation are fly ash and bagasse ash. Fly ash was collected from the Bangladesh Barapukuria Power Station and sugarcane bagasse ash was collected from Rajshahi Sugar Mill. After that the collecting samples were taken in the laboratory and dried for 24 hours. Then the sample was subjected to a number of laboratory tests including specific gravity test, liquid limit test, plastic limit test, shrinkage limit test, modified proctor test and California bearing ratio test to 
find out the engineering properties. AASHTO and ASTM standards are applied in order to determine the engineering properties of soil. Soil sample is mixed with various percentages of fly ash and bagasse ash separately and performed modified proctor test to find out optimum moisture content and maximum dry density of soil sample after mixing with admixtures. Then CBR test is conducted in unsoaked condition. The soil sample is prepared with its optimum moisture content and compacted in 5 layers by giving 56 blows to each layer by $4.89 \mathrm{~kg}$ hammer. After then it is placed on the penetration test machine to find out the CBR value.

\subsection{Properties of Soil Sample}

The soil sample was fully oven dried, weighed and stored in room temperature. After that, the general properties of the soil were tested in the laboratory. The soil was tested for liquid limit, plastic limit, shrinkage limit, plasticity index, optimum moisture content, maximum dry density and CBR test. The CBR value, delineates the bearing capability and strength of soil. CBR needs to be analyzed, for overestimated result, it will denote high tendency of un-satisfactory highway performance and premature failure. On the other hand, for the underestimated $\mathrm{CBR}$, the pavement will become thicker, stronger than previous but un-economical [13]. Consequently, CBR is an important parameter considering about the road pavement materials' suitability or otherwise for: sub-grade, capping, sub-base or base.

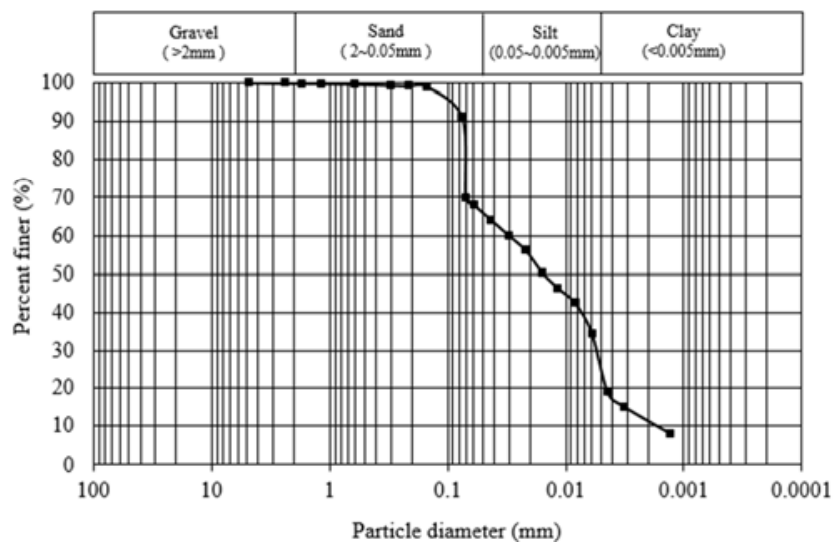

Figure 1. Grain Size Distribution Curve.

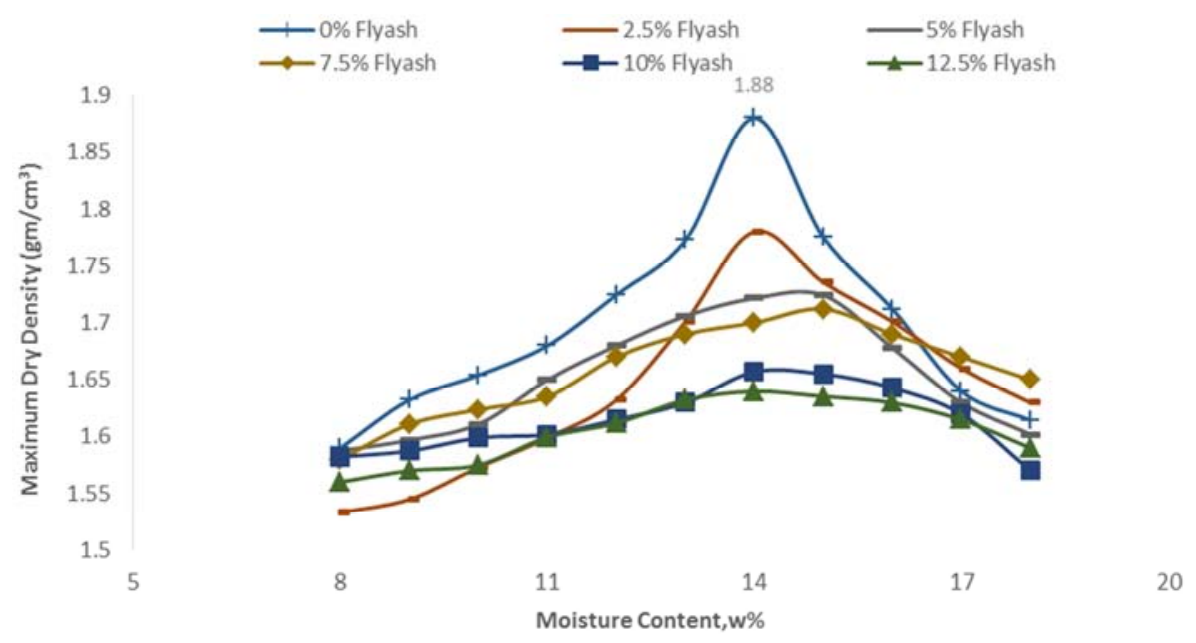

Figure 2. Moisture Content \& Maximum Dry density of soil with different percentage of Fly Ash.

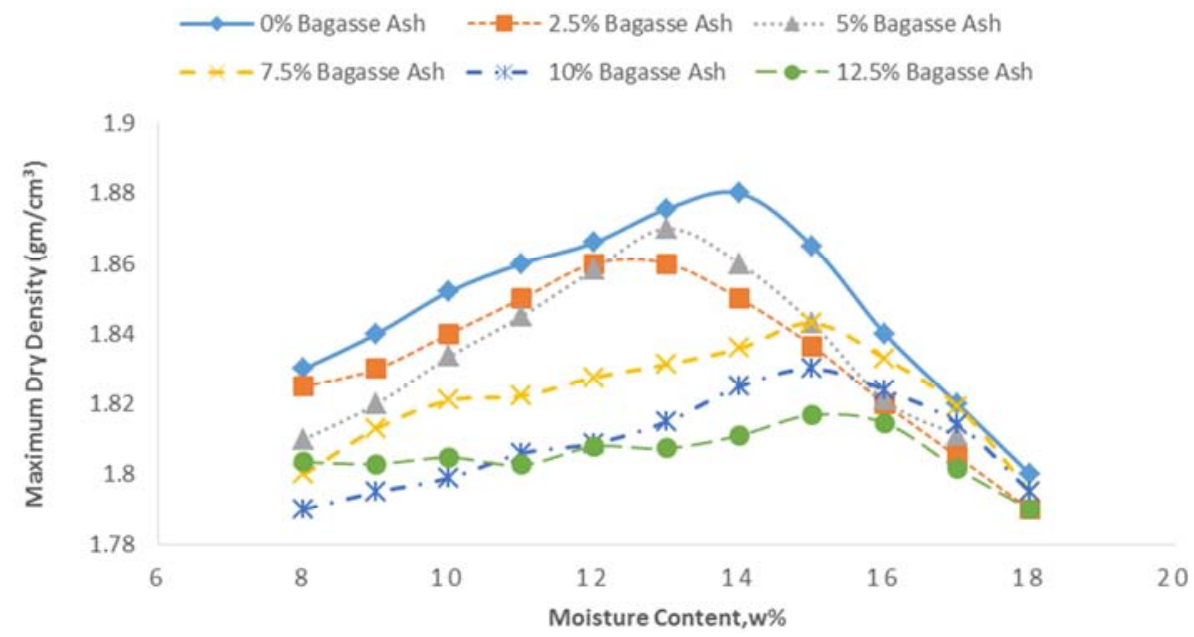

Figure 3. Moisture Content \& Maximum Dry density of soil with different percentage of Bagasse Ash. 
Comparison of OMC values

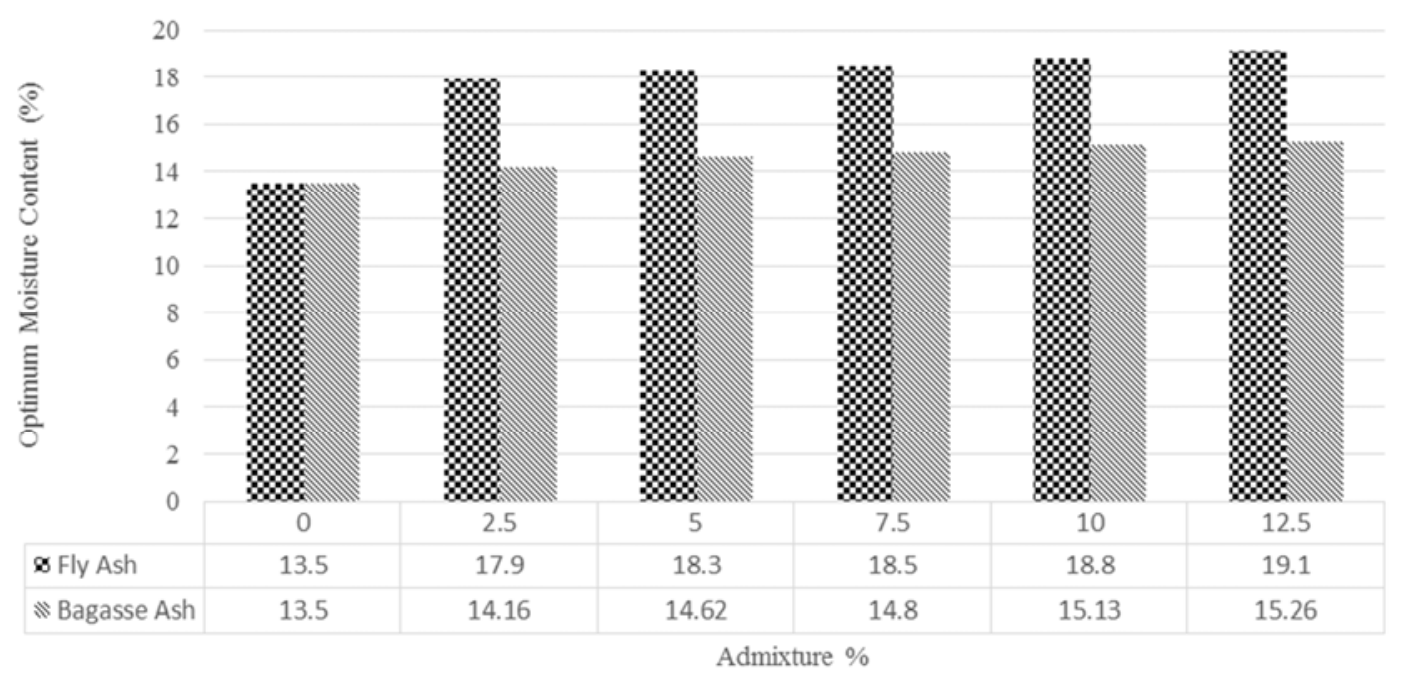

Figure 4. Optimum moisture content of soil with various percentages of Fly Ash and Bagasse ash.

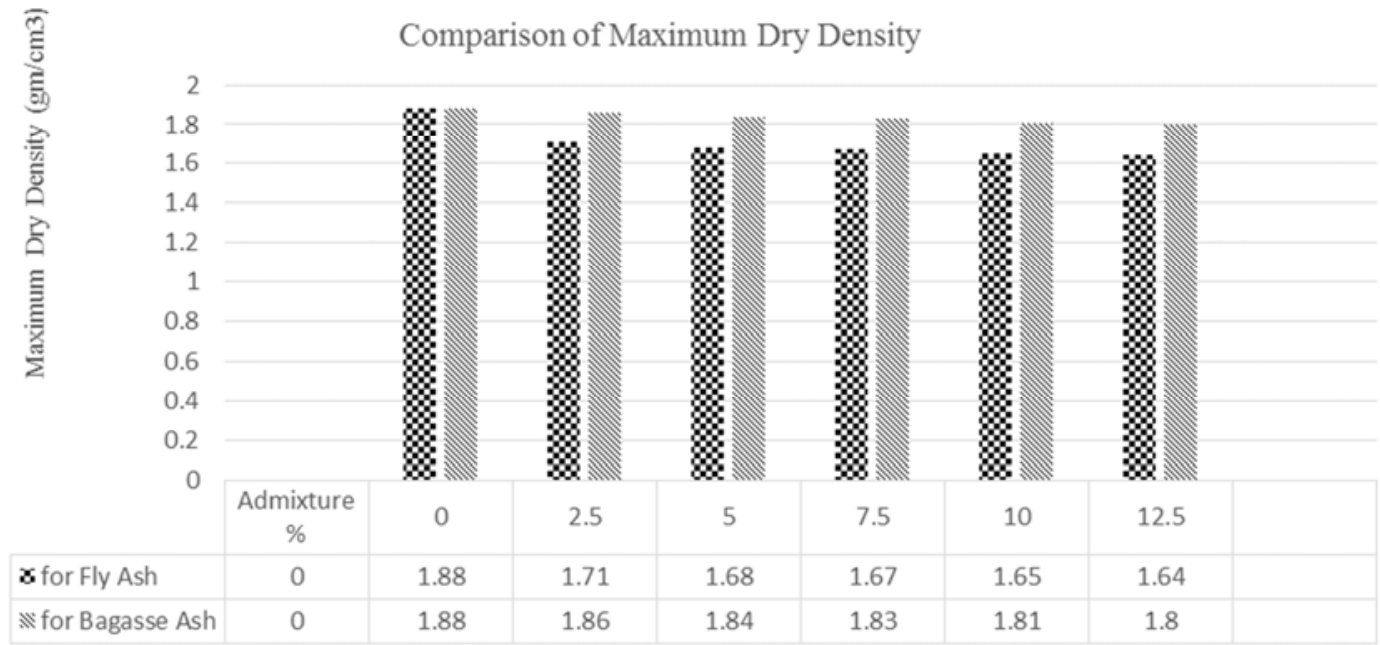

Figure 5. Maximum Dry Density of soil with various percentages of Fly Ash and Bagasse ash.

Comparison of CBR values between Fly Ash \& Bagasse Ash

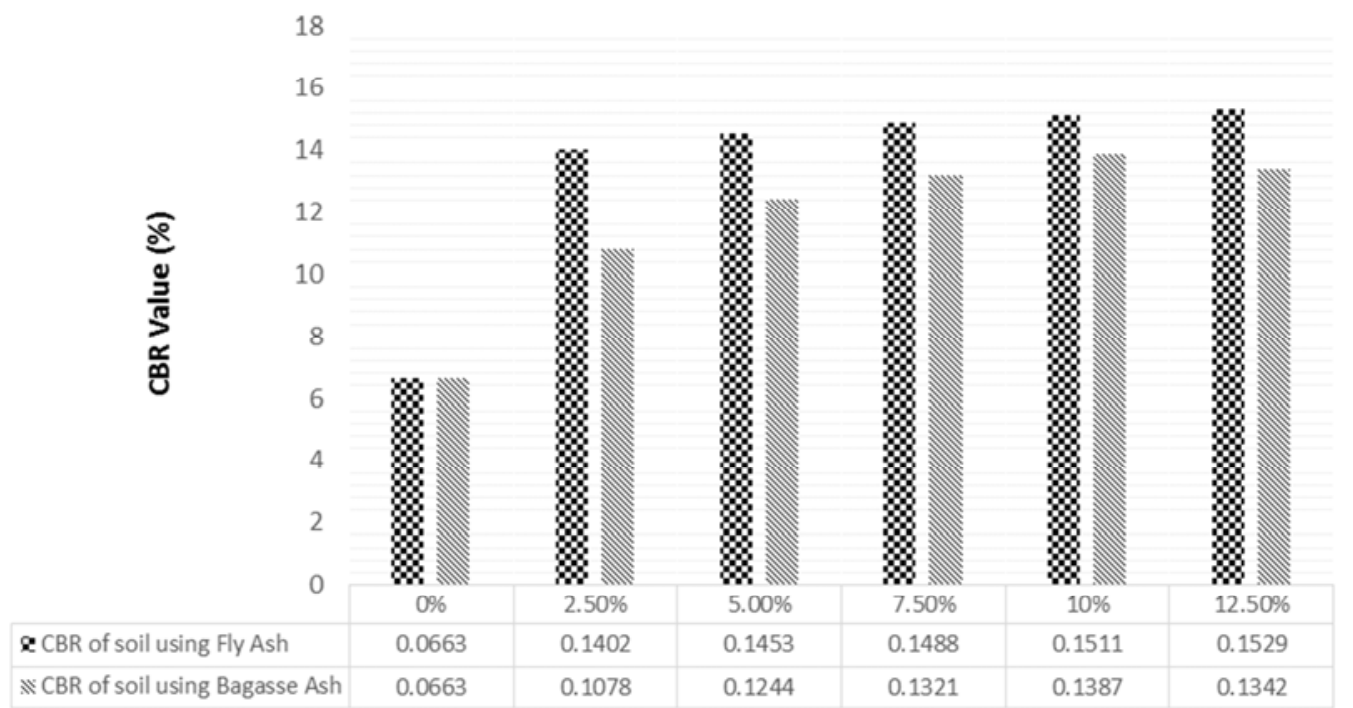

Figure 6. CBR values of soil with various percentages of Fly Ash and Bagasse ash. 
Table 1. Fundamental engineering properties of soil.

\begin{tabular}{ll}
\hline Properties & Value \\
\hline Textural classification & Clay Loam \\
Sand content (\%) & 35 \\
Silt content (\%) & 40 \\
Clay content (\%) & 25 \\
Specific gravity & 2.64 \\
Liquid limit (\%) & 58.43 \\
Plastic limit (\%) & 30.21 \\
Shrinkage limit (\%) & 17.36 \\
Properties & Value \\
Plasticity index (\%) & 28.22 \\
Optimum moisture content (\%) & 13.5 \\
Maximum dry density (gm/cm3) & 1.88 \\
California bearing ratio (\%) & 6.63 \\
\hline
\end{tabular}

Table 2. Chemical composition of Fly ash.

\begin{tabular}{ll}
\hline Oxide & Percentage \\
\hline $\mathrm{SiO}_{2}$ & 54.4 \\
$\mathrm{Al}_{2} \mathrm{O}_{3}$ & 35.6 \\
$\mathrm{Fe}_{2} \mathrm{O}_{3}$ & 2.9 \\
$\mathrm{TiO}_{2}$ & 3.2 \\
$\mathrm{Mn}_{3} \mathrm{O}_{4}$ & 0.11 \\
$\mathrm{CaO}$ & 0.56 \\
$\mathrm{~K}$ & 0.66 \\
$\mathrm{Na}$ & 0.06 \\
$\mathrm{MgO}$ & 0.18 \\
$\mathrm{P}_{2} \mathrm{O}_{5}$ & 0.46 \\
$\mathrm{SO}_{3}$ & 0.13 \\
\hline
\end{tabular}

Wardell Armstrong (1991) [14].

Table 3. Chemical composition of Bagasse Ash.

\begin{tabular}{ll}
\hline Oxide & Percentage \\
\hline $\mathrm{SiO}_{2}$ & 78.34 \\
$\mathrm{Al}_{2} \mathrm{O}_{3}$ & 8.55 \\
$\mathrm{Fe}_{2} \mathrm{O}_{3}$ & 3.61 \\
$\mathrm{CaO}$ & 2.15 \\
$\mathrm{Na} \mathrm{O}_{2} \mathrm{O}$ & 0.12 \\
$\mathrm{MnO}$ & 0.13 \\
$\mathrm{TiO}$ & 0.50 \\
$\mathrm{MgO}$ & 1.65 \\
$\mathrm{BaO}$ & $<0.16$ \\
$\mathrm{P}_{2} \mathrm{O}_{5}$ & 1.07 \\
$\mathrm{~K}_{2} \mathrm{O}$ & 3.46 \\
\hline
\end{tabular}

Corderio, et al. (2004) [15].

\subsection{Preparation of Admixtures}

Fly ash was collected from the Bangladesh Barapukuria Power Station and sugarcane bagasse ash was collected from Rajshahi Sugar Mill. After collecting the fly ash it was dried in the oven. And Sugarcane Bagasse ash was dried in air for 3-4 days. Then it was burnt into fire. After burning sugarcane bagasse was turned into ash form. Finally the admixtures were sieved through IS Sieve No. $200(75 \mu)$ in order to achieve a uniform powdery [18].

\section{Results}

The following grain size distribution curve is found by using the data obtained from sieve analysis and hydrometer analysis of soil.

After performing Modified Proctor Test the following moisture content and maximum dry density was obtained.

\section{Discussions}

According to Textural classification (U. S. Bureau of Soil and Public Road Administration (PRA) classification) from grain size distribution curve it is found that the soil sample is clay loam. As the liquid limit of soil is $58.43 \%$ and plasticity index is $28.22 \%$ from the plasticity chart, it has been found that it is a medium plastic soil [16].

From the figure 2 it is seen that the addition of fly ash and bagasse ash separately by weight $(0 \%, 2.5 \%, 5 \%, 7.5 \%, 10 \%$ and $12.5 \%$ ) to the soil sample caused an increase in the optimum moisture content and caused a decrease in maximum dry density [17]. But for fly ash the rate of increment of $\mathrm{OMC}$ is relatively higher than the bagasse ash. In case of maximum dry density for different percentages of mixing admixtures, bagasse ash gives the greater value compared to the fly ash.

From the figure 4 it is found that the addition of fly ash gives better CBR value than the bagasse ash. With the increasing percentages of fly ash CBR value is continuously increasing. After $10 \%$ addition of bagasse ash the CBR value starts to decrease. For that reason, $10 \%$ is the optimum value for bagasse ash. On the contrary, for $10 \%$ fly ash the CBR value is $15.11 \%$ and for same percentage of bagasse ash the CBR value $13.87 \%$, which is less than the fly ash.

\section{Conclusion}

Both Fly ash and Bagasse ash are suitable for expansive soil stabilization. And Fly ash is more suitable than the bagasse ash for soil stabilization. With the increasing percentages of fly ash, the governing factor CBR value is continuously increasing. The research work shows the optimum percentages for Bagasse Ash is $10 \%$. That shows a clear statement that the most suitable sub grade material for same percentage of admixtures is Fly ash can be a good replacement of Bagasse ash. Through comparing the most effective subgrade material governed by CBR values we delineate on improvising of flexible pavement design due to expansive soils.

\section{References}

[1] Somaiya, P., Zala, Y. and Dangar, R. (2013), 'Stabilization of expansive soil using fly ash', Available in: https://www.researchgate.net/publication/280153059.

[2] Ahmed, B., Rahman, A. and Das, j. (2015), 'Experimental study on effect of sugarcane bagasse ash on CBR value of subgrade soil', International Conference on Recent Innovation in Civil Engineering for Sustainable Development.

[3] Mohanty, M. K.(2015), 'Stabilization of expansive soil using fly ash'. 
[4] Anu. K., Gurung, D., Yadav, R., Lollen, L. and Bhutia, P. N. (2016), 'Stabilization of soft clay soil using fly ash and lime stone dust', International Journal of Scientific \& Engineering Research, Vol. 7, Issue 5, May 2016- Available in: http://www.ijser.org.

[5] Najar, I. A., Sharma, D. and Kumar, M. (2017), 'A review paper on the experimental investigation on the use of bagasse ash in the construction of low volume traffic roads', International Research Journal of Engineering and Technology (IRJET), Vol. 04, Issue 09, September 2017Available in: www.irjet.net.

[6] Murali, K., Ashok, S., Giridharan, N., Pandiarasan, K. K. and Logesh, P. (2018), 'A review on stabilization of expansive soil with various admixtures', International journal of scientific and research publications, Vol. 8, Issue 4, April 2018Available in: http://dx.doi.org/10.29322/IJSRP.8.4.2018. P 7629.

[7] Phanikumar, B. R. and Sharma, R. S. (2004), "Effect of Fly Ash on Engineering Properties of Expansive Soil", Journal of Geotechnical and Geo environmental Engineering. Vol. 130, Issue 7, pp. 764-767.

[8] Ozdemir, M. A. (2016), 'Improvement in bearing capacity of a soft soil by addition of fly ash', Advances in Transportation Geotechnics 3. The $3^{\text {rd }}$ International Conference on Transportation Geotechnics (ICTG 2016), Vol. 143, Pages 498-505, 2016.

[9] Ahmed, A. G. A. (2014), 'Fly ash utilization in soil stabilization', International Conference on Civil, Biological and Environmental Engineering (CBEE-2014), May 27-28, 2014 Istanbul (Turkey)-Available in: http://dx.doi.org/10.15242/IICBE.C514601.

[10] Goliya, H. S., Faraz, M. I. and Singune, V. (2018), 'A review paper on fly ash and bagasse ash using as a sub-grade stabilizing material', International Journal for Research in Applied Science \& Engineering Technology (IJRASET), Vol. 6, Issue VI, June 2018- Available in: www.ijraset.com
[11] Kanchan Lata Singh and S M Ali Jawaid, (2013), "Geotechnical Properties of Soil Stabilized with Bagasse Ash", IJBSTR REASEARCH PAPER, ISSN 2320-6020, Volume 1 [ISSUE 9].

[12] Kiran R. G. and Kiran L. "Analysis of strength characteristics of Black cotton soil using Bagasse ash and additives as stabilizer", IJERT, issue 7 (2013).

[13] FMW, "Highway Manual Part 1: Pavement and Materials Design," Federal Republic. of Nigeria., vol. III, no. March, 2013.

[14] GSB Report Bakr et. al (1996), Geology exploration Report of Barapukuria Coal Mine Bangladesh, Geology and Coal deposit of Barapukuria Basin, Dinajpur District, Bangladesh (Wardell Armstrong 1991).

[15] Cordeiro, G. C., Filho, R. D. T., Fairbairn, E. M. R., Tavares, L. M. M. and Oliveira, C. H. (2004), 'Influence of mechanical grinding on the pozzolanic activity of residual sugarcane bagasse ash', Use of Recycled Materials in Building and Structures, November 2004.

[16] B. M. Das, Principles of Foundation Engineering, 7th ed. Stamford, USA: Cengage Learning, 2007.

[17] Phanikumar, B. R., Naga Reddayya, S. and Sharma, R. S. (2001), "Volume Change Behavior of Fly Ash Treated Expansive Soils", 2nd International Conference on Civil Engineering, Indian Institute of Science, Bangalore, India. Vol. 2, pp. 689-695.

[18] Prakash Chavan and Dr. M. S. Nagakumar, (Aug 2014), "Studies on Soil Stabilization by using Bagasse Ash", IJSRET, ISSN: 2278-0882.

[19] Ken C. Onyelowe (2012). Cement Stabilized Akwuete Lateritic Soil and the Use of Bagasse Ash as Admixture. International Journal of Science and Engineering Investigations, Volume 1, Issue 2, pp. 16-20. 